\title{
Radiological Figure Quality and Compatibility in Published Articles
}

\author{
(D) Serkan Arıbal, (1) Eyüp Kaya, (1) Tanju Kisbet, (1D Hakan Önder \\ University of Health Sciences Turkey, Prof. Dr. Cemil Taş̧̧ığlu City Hospital, Clinic of Radiology Service, ístanbul Turkey
}

Keywords: Radiological image, figure, figure legend

\section{Dear Editor,}

We read with great interest, the case report by Tutar et al. (1) entitled "Lymphoepithelioma of Larynx: Case Report", which was published in December 2020 (volume 36, issue 4) in the European Archives of Medical Research. The authors presented a rare case in this didactic, well-designed, and well-illustrated article. However, necessary matters are pointed out about the radiological figure. The authors mentioned, "The lesion invaded the arytenoid cartilage and extended into the paralaryngeal area and fat planes (Figure 2a, b)". However, Figure 2 presented two axial contrast-enhanced neck computed tomography images with almost the same level and location in the soft tissue window. The multiplanar reconstructed images were not chosen, particularly the coronal planes, to show the lesion extensions through the laryngeal area and the destruction of the mentioned cartilaginous structures. Therefore, the presence of lesion invasion in the arytenoid cartilage is unclear. These figures do not meet the terms mentioned in the article. Furthermore, figure legends or notations were not provided. The authors and persons responsible for the peer-review processes are reminded to pay particular attention to this issue in such well-designed articles, where didactic quality is at the forefront.

The main problem of an article without a radiologist coauthor was reported as follows: Unacceptable poor quality figure legends, unmentioned imaging modality, undescribed imaging findings, unblinded patient data, and low image quality (poor spatial orientation, poor image resolution, suboptimal contrast, and absent or poor cropping). A study by Luyckx et al. (2) concluded that involving a radiologist as co-author in the publication significantly improves its quality.

\section{Ethics}

Peer-review: Internally peer-reviewed.

Concept: S.A., Design: S.A., E.K., Data Collection or Processing: S.A., T.K., Analysis or Interpretation: S.A., H.Ö., Literature Search: S.A., E.K., T.K., H.Ö., Writing: S.A.

Conflict of Interest: No conflict of interest was declared by the authors.

Financial Disclosure: The authors declared that this study received no financial support.

\section{REFERENCES}

1. Tutar B, Akgün F, Ahmed IA, Berkiten G, Saltürk Z, Uyar Y, Özay Nayır P. Lymphoepithelioma of Larynx: Case Report. Eur Arch Med Res 2020;36:285-8.

2. Luyckx E, Bosmans JML, Broeckx BJG, Ceyssens S, Parizel PM, Snoeckx A. Radiologists as Co-Authors in Case Reports Containing Radiological Images: Does Their Presence Influence Quality? J Am Coll Radiol 2019 Apr;16(4 Pt A):526-7. 